\title{
The role of prednisolone in acute urticaria management
}

\author{
Kiran Godse \\ From EAACI Skin Allergy Meeting 2014 \\ Krakow, Poland. 18-20 September 2014
}

\begin{abstract}
Aim
To evaluate the efficacy of a 5 day short course of oral prednisolone when added with levocetirizine for management of acute urticaria.
\end{abstract}

\section{Materials and methods}

Prospective, randomized clinical trial was carried out in a teaching hospital.

All patients were asked to evaluate the severity of pruritus on urticarial activity score (UAS).

Patients were then given oral prednisolone $30 \mathrm{mg}$ for 5 days and tablet levocetirizine $5 \mathrm{mg}$ twice daily for 6 weeks and only levocetirizine tablet $5 \mathrm{mg}$ twice daily for 6 weeks. Patients' conditions were reassessed clinically with UAS calculated again 2 days later and again 5 days later.

\section{Results}

49 patients were enrolled; 24 patients received prednisolone with Levocetirizine and 25 received only Levocetirizine. The two groups had similar UAS at enrollment (prednisolone, 4.6 ; levocetirizine ,4.4 ) , but at 2- and 5-day follow-up the prednisolone group had significantly lower UAS (1.4 and 0.2 versus 3.8 and 2.4 respectively) and greater clinical improvement in rash. Response did not correlate with age, sex, or identification of an allergen. No adverse effects were noted in levocetirizine group. In Prednisolone group two patients complained of gastritis.

\section{Conclusion}

At the end of 6 weeks, 3 patients from the steroid group and 8 patients from the levocetirizine group continued to get urticarial wheals. The addition of a prednisolone short course improves the symptomatic and clinical response of acute urticaria to antihistamines. Patients with steroids

Patil hospital, Navi Mumbai, India

(c) 2015 Godse; licensee BioMed Central Ltd. This is an Open Access article distributed under the terms of the Creative Commons Attribution License (http://creativecommons.org/licenses/by/4.0), which permits unrestricted use, distribution, and reproduction in any medium, provided the original work is properly cited. The Creative Commons Public Domain Dedication waiver (http:// creativecommons.org/publicdomain/zero/1.0/) applies to the data made available in this article, unless otherwise stated.
doi:10.1186/2045-7022-5-S1-O8
Cite this article as: Godse: The role of prednisolone in acute urticaria management. Clinical and Translational Allergy 2015 5(Suppl 1):08.

Submit your next manuscript to BioMed Central and take full advantage of:

- Convenient online submission

- Thorough peer review

- No space constraints or color figure charges

- Immediate publication on acceptance

- Inclusion in PubMed, CAS, Scopus and Google Scholar

- Research which is freely available for redistribution

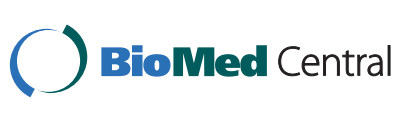

improved more quickly and completely without major adverse effects.

Published: 11 March 2015 